\title{
Looking Into The Future With Hopeful Eyes ${ }^{1}$
}

\author{
Olcay Kırışoğlu \\ olkiris@gmail.com \\ Mustafa Kemal University, Hatay
}

\begin{abstract}
The current century we are in, is an age of change and transformation. Change in a positive meaning is the first step of developing, with a transformation of a forward looking face through creativity, notion and values. Today, Contemporary culture, Contemporary art, s Contemporary society and of course Contemporary mankind is mentioned with different discourses and different values. As a result of all of the transformation related to contemporary culture, art and society transformation in this paper focuses on key points related to critical reactions; dead end to criticism, social upheaval and consumption frenzy, culture and education policy, the reflection of change on the art education and aim limits in art and culture education.
\end{abstract}

Key words: Art education, Culture education, Transformation, Criticism, Culture and education policies

\footnotetext{
${ }^{1}$ Paper presented at Anadolu International Symposium on Arts Education, Eskisehir, May 14, 2014
} 
'Years later two very old friends come across each other. One says to the other, "You haven't changed at all'. The others face starts getting pale. Not changing has upset her. Bertolt Brecht' Changing is a fact of life and maybe a necessity. But, it is desired for this change to be meaningful and enriching. Change in a positive meaning is the first step of developing, with a transformation of a forward looking face. Within this context transformation is creative, active and is a permanent stage looking forward for development. Changing and transforming by advancing at the same time is renewal. As for every renewal, it hides clues of another change within itself. Exactly like a completed work of art that hides the clues of the next coming work of art.

The current century we are in, is an age of change and transformation. This change enforces us to review once again all of the acquainted definition, notion and values. Today, Contemporary culture, Contemporary art, s Contemporary society and of course Contemporary mankind is mentioned with different discourses and different values. Change at the same time is expanding rapidly. Even though the same conditions do not occur in every country and although change is actualised differently in each country, it still transcends each country boundaries easily and is perceived everywhere simultaneously.

Hereby the word Contemporary is used to clarify the time frame at present. Otherwise in order to explain development in every aspect, I should have used the word Contemporaneous (up to date) as suggested by Aziz Nesin.

Contemporary Culture: Today most of the familiar definitions do not exactly satisfy the answer to our question "What is contemporary culture?". For example; "(Culture.... is the wholeness, created by human beings as a special concept which consists of knowledge , belief, art, justice, tradition and other abilities) an integrity of man as a social individual while acquiring information, belief, art, law, tradition other competences and customs"” (Tylor, 1871);or " the 
entire reality that exists within mankind, that is put forward" (Uygur,2003); or" It is everything that mankind creates against nature" ...types of definitions do not include dilemmas, are definitions that declare totalitarian meaning. According to these definitions, society exists with culture associations, their values and their convention. People whom are engaged in material and moral efforts; again whom create material, moral culture and humans who are brought up in the created culture values at the same time becomes a part of that culture. Thus this is how national cultural identities are created.

Whereas today, contemporary culture is mentioned together with; pluralism, multiculturalism notions. Pluralism and multiculturalism takes into account many groups and also the society's creative capacity, values and evaluates that community according to this difference.

Anthropologist's evaluation in this matter namely: "Every culture group keeps its existence in the values that they have created. Every group's culture is valuable". By this way the multiculturalism notion is opened for discussion.

Cultural Anthropologist tend to identify most example of visual symbolism embellishment as art. This is a denoting, identifying function and does not necessarily make a value judgment about the quality of the art form (McFee, 1972),

It is said; - Every object that is emerged after human creative action, according to the elitist understanding is that, even if it is not attributed as a high culture product, it should be defined as a cultural existence for that community, and should be recognized.

According to this approach, the existence of culture has been made in intention to a purpose, and appears before us as a definition that covers all objects that affect the audience or the user, leaving a qualitative awareness. Thereby the boundaries between subculture - superior culture will dissolve. This situation will enable for acceleration to be gained for popular culture and also the most effective area of popular culture being visual culture. Although this change will 
not be formed simultaneously for every country, at the same time, the results are sometimes politic, sometimes economic and also is effective in cultural context.

Whilst in some countries regarding cultural development "is it local? / is it universal?" is it national? / is it international?"...types of notions are discussed and the concerns that external cultural impact will eliminate the identity of national, cultural identity the communities find themselves all of a sudden in a completely different complexity as in popular and visual culture.

On the other hand while globalisation with a variety of discourses and routes have no limits to countries cultural, economic, technologic, politic affects, in visual context the boundaries with media, especially digital technology resources are easily outdistanced. With the dimension of having no limits, visual culture also including visual arts creates a crossbreed culture environment with all its positive negative aspects by combining with local culture objects.

This time nations, beyond discussions of "Is it national? Is it universal?" are confronted against cultural expansionism. Against this cultural expansionism it has become more difficult to protect the cultural identity.

Contemporary art: While contemporary art is in this situation, with what type of changes is modern art brought to the agenda? As the definition for culture expands modern art is also brought to the agenda with new discourses. Namely; Contemporary art is precisely the kind of art that encourages pluralism, for it is based on the creative transgression of every thinkable standard and the re-definition of every possible self-definition. The arts system thus changed into fragmented space, marked by aesthetic anomie and driven forward by anaesthetic vanguard which again and again looks for artistic possibilities outside art) "(Learmans,2002).

Anthropologist's view of cultural pluralism brings different evaluations to art. With this approach in art, formalist aesthetic in one sense is rejected as a sole criterion, aesthetic experience mainly becomes distant as a sole purpose of art. Under the name of democratisation 
Anadolu Journal of Educational Sciences International, Art Education Special Issue, November 2015

of art, the artistic values hierarchies (in value prioritisation) has a tendency in a sense of emerging exclusion.

As a result of all of these discussions in summary;

- Especially the boundaries of objects that are mentioned in definition types of visual arts such as popular culture/ elitist art/ folk art will dissolve, the order of importance will be removed.

- Popular culture addresses the larger masses, taking some of its aspects from the foundation of conventional folk art, and from another aspect it is accepted by large masses as a necessity of democratisation for a culture product. Popular culture easily expands with new technology. With dramatic changes instantly becomes a current issue, manipulates society and with the same speed drops from being a current issue.

- All of the properties of Post-modern discourse, by questioning hierarchy in art, dissolving of boundaries, changes of eclectic structure and social value systems etc. types of statuses becomes effective in work of art.

- Boundaries in art do not dissolve in absolute figuration, it expands with historical, social, cultural, political, ethical concept of themes. Meaning gives more importance over style.

- The valuable philosopher Ionna Kucuradi says in one of her articles;. "A work of art not only touch us, but they teach us as well. This is why they constitute a valuable material for ethical education through art" (Kucuradi, 2004). Therefore for images, besides beautiful or apart from including ethics many more meanings and functions are undertaken.

- All kinds of visual images enters our lives in order to create our cultural identity. As much as the variety of images, the multiplicity of meanings also become a current a current issue. Among such an amount of image variety and vast amount it was already difficult to select visual arts for our creative world, now it has become more difficult. When we add the digital virtual world it is obvious how enlarged, how increased the impact area has become for the visual arts world.

- And certainly with every change new formations are brought to the agenda. In the fast communication age, societies pass on to visual image culture to a large extent instead of literary. Visual - literacy becomes prominent, and from now on visual image repertoire is mentioned more than vocabulary. All of these in a sense are indicators of change in culture and art concept.

While new popular culture elements, visual images are becoming widespread, work of art also takes it share of this popularisation. You can find Van Gogh's Cafe Terrace at Night on a 
handbag, Monet's Water Lily on a t-shirt or on a glasses case. It can be argued that for the sake of transmitting art on a promotional basis with cheap prints to the low end consumers. But, the images of this popularised visual art become ordinary in a short time.

Opposing to all this complexity it is important to develop critical reaction. And here as much as to educators, critics also have important tasks assigned to them. In this regard I wonder if critics are able to perform their lighting our way functions.

Dead End to Criticism: In this day and time knowledgeable, divertive, elucidative criticism in a sense is considered to take into account for the market and consumers service in objects that are functional to ordinary popular pleasure. The critics have fallen into dilemma. What will they do? How will they build a bridge between the art society they live in and between the society? Will they be the spokesman for the wide consumer mass, or will they be on the side of art and artists? In this matter danger is put into words like this;.”'( The rising the significance of community-based cultures, the increased targeting of niche markets

, the dissolution of the boundaries between high and low culture, and concomitant ethic and geographic diversity audience have lessened and even delegitimized the need for dominant , centralized critical voices "(Berger,1998:6). Here once again it is up to the critics as well as, of course, the educators to balance between.

Social Upheaval and Consumption Frenzy: Whilst this change and transformation process is being lived in modern culture, modern art and in popular cultures most active field being visual culture, society and of course human existence at full speed is affected.

Social upheaval is multi-dimensional. Rapid living conditions, excessive structuring, Market economy that embraces society, whilst this change and transformation process that is focused on consumption and advertisements that keep pumping consumption, the image conflict that these create and visual pollution, non-recyclable production and consumption objects packaging, effects human existence vastly. 
Dr. Atabek, explains social upheaval this way. In a society's change "firstly the standard of value judgement changes. Then everything starts to change, so much that you will not be able to recognise yourself" (Atabek 2003).

It is mostly that youth is affected by social upheaval. Upon this group that is trying to create an identity for themselves with popular images is affecting their standard of judgement as much as possible with commercially designed and consumer based market economy with brands. It is not only the absolute brand appeal that is effecting the youth's standard of judgement. The fast affected and fast consumed face of music, dance, cinema, comic strips etc. of popular culture has a principle role in this affection. When we add the digital visual world's resources the extensive impact field can be understood. This way the negative direction of change in societies is inevitable.

Now the values are listed like the following:

- Being a productive individual to becoming a non-questioning consumer,

- Being a creative individual, to becoming a ready user,

- Labour, to easy income achievement,

- Necessity, to brand addiction,

- Shopping for necessity, to entertainment,

- Social status, has transformed to showing off.

In conclusion, being a productive individual, being creative, being productive has dropped to lower levels on the value index. The most active areas is the consumer markets for popular visual images in different manners, embracing society with different meanings and aims.

When mentioning the consumer market shopping malls should not be the only thing coming to your mind. Television soap operas, advertisements, computer games, internet etc. everything 
makes our criticism competence blunt and keeps us captive. Whilst doing this we emphasize different life styles than we live, doing this by using aesthetics intensively for a different purpose. Creates an elaboration in society. In this way especially our children and adolescents are obligated under new social, economic, cultural notion bombardment. Being accepted without being questioned, with a variety of appealing visual culture objects, person's visual image paths that reaches us and consequently turns us upside down with society's value systems.

It is said that; "“'Never before in human history has imagery been so central to the creation of identity" (Chaplin, 1994" (Chaplin, 1994), and. and "Never before has the aesthetic styling of products been so intense" (Lush, Urry, 1994)

The only way to get rid of the social corruption is correctly detected culture, education, and from our point of view, art and culture education policies. To list the value systems in a linear ordering, to improve today's conditions in accordance with the benefit of individual and social aim in the country conditions, it is mandatory to bring up individuals by using science, art, advancement in technology, modernity, individual, cultural development services. The initial condition for this is to, determine the meaningful and beneficial culture policies.

\section{Culture and Education Policies:}

Culture policies; to develop the cultures in a country's universal level, the coordinated policies in order to protect the cultural properties of cultural roots that should remain for the future. In this context it is the government institutions, local authorities, social society organisations, universities and even individually each artists and units of the world of art, educators create the cultural policies. 
Definitions normally emphasize what should be. For this reason while these cultural policies are being generated it is very difficult to infer meanings on behalf of change in today's system with definitions that bring us negativity.

As modern culture, modern art, modern society and modern man, change in every dimension and transformation that is lived bound to this change, it is said that cultural policies should also develop the prospective sides in order to develop further this change to configuration.

But; with this configuration; like a famous statesman has said; "Science and art should not be the duty of the government. In other words "Evaluation of culture and art in terms of quality should not be abandoned to persons whom give decisions based on forward looking fictionalisations" (Thornbecke, 1798-1872).

A researcher says that; for constitution of culture policies; "If it is dealt with a politician, or an educator, there is no greater destruction for a folk society than a bad politician" (Uygur, 2003).

If this is the case culture policies should be the duty of the artist, also the educator and also the art educator.

Institutions that are in every culture group with their own separate value and necessities, should form their own culture policies according to their historical substructure, traditions, values and also geographical location. It is important here to establish correct cohesiveness and balance between institutions. Culture policies should be inclusive, embracing, and supportive. The created culture policies are not the only implementers of the educators, at the same time as they are the policy creators they are able to keep the balance, and correlate between the culture policies.

The transformation in concept of the culture, society is also reflected on the education policies. For this reason the artist, educator, especially when the art educator lives in this era of time, is 
the first to intuit this culture change. The art educator is the first to intuit this change and also is the person whom will embed this transformation the most meaningful, and should be so. Accordingly all of the change lived, reflecting the modern implementation of the transformation, should take the active role determining meaningful routes.

\section{The Reflection of Change on the Art Education:}

Today on behalf of change and transformation it has been necessary to look at what has happened in art, society, culture to chart out a new road map for art education. In this road map, the change and transformation in every field will be effective to define.

In this context we should address the following questions to ourselves:

- How art and visual culture education should be formed according to this change and transformation and with which reasons and aims?

- What type of art and culture education should we fictionalise according to these aims?

- What should be the contents of the programmes of instruction? In what dimension should the visual culture that has been presented to us from popular culture be among the visual culture programmes?

- How much, in which measure should the historical, cultural, economic, political matters in socio-cultural context be put in programmes?

\section{Aim Limits in Art and Culture Education:}

It is regarded necessary to have an approach in art and culture education that is appropriate according to these changes by concentrating on changing society. Even if certain changes that have happened in the past are not the same as today, the implemented general framework presents us certain clues for today.

In the historical process of art education on an intellectual, social, cultural period based age has been shaped according to necessities of society's and individuals. Programmes of instruction 
have been arranged according to the determined policies of these changes, and the implementations have been conducted accordingly.

From the past until today these period of changes that are non-stationary, have sometimes enlarged in the limit of aims, and sometimes have withdrawn in its own boundaries of art.It is necessary to mention that these discourses concerning art sheds light for us.

When art is directly based upon, for example, "art is a world in itself" or in a more common discourse "art for art's sake".. types of self-directed art discourses has become active in art education. The art that has come to the agenda with these types of discourses have been placed into the instruction programmes directly with its own values. With this approach it is very important the instruction of art information within all dimensions.

Today all of the changes that have been lived, value slippage in society, wide spreading of popular culture, pluralism in definitions and notions, change in art, consumer weighted economy, has brought the art and visual culture education to the agenda with a different discourse.What is this discourse? "Art is changing the world".It is said that; "Art and visual culture education", to change society and individuals should be a powerful education tool in the concept of historical, cultural, and morale.We should not be unconcerned regarding social, cultural, political and economic fields of transformation. Art in the transformation of this framework, should be formalised according to the reconstruction of society. But; such kind of aim boundaries that have spread so much, of art and culture education at hand in socio-cultural context becomes effective in bringing up individuals in declining to what is happening, questioning, criticizing, analysing and being reactive in a creative concept.

How should art education be structured under such big responsibility that our children and adolescents can feel pleasure of art work in this complex visual culture environment and be able 
to distinguish between the valuable visual culture objects and the common ones and also be able to put forth their reactions with their

In this concept we can list the first of all actions to be taken this way:

- With such an environment of intense visual and popular culture to develop visual literacy, it looks inevitable to have an art and visual culture education made aimed for an educated eye in critical meaning. For these reasons before anything else education should be focused on gaining a durable critical eye. Commercial or not, a popular culture product or high art, is a critical substructure gained before high art based aesthetic concept. It is only then that it is possible to evaluate a variety of visual culture forms and not only art. And it is only then that it can get easier to distinguish between the popular culture and valuable culture. It must not be forgotten that, aesthetic criticism is the base condition in visual literacy for art education.

- Criticism only constitutes a step of art education. An individual who looks in their environment with a critical eye should learn to give their own reaction with their own creativity. Exactly like an artist, should explain their senses to life and environment with work of art. Here transformation cannot be on only subjects, all types of technology that the age presents should be used.

Creations continue with digital technology, new media possibilities and virtual environment. This way it will not be possible to remain insensitive both for the environment, also for society and social fact events and also modern art. The disconnection between art education and the art world will eliminate and continuity will be maintained in education. Art and culture education that shows this type of structure will not only enlarge in its aims but will also gain appearance between interdisciplinary subjects. But it is important not to escape from the attention an important matter.

When I mention that I am keeping the art education aim boundaries wide in an art route, if we only reduce art and visual culture education study to social, cultural, economic, political subjects then, "Art and culture education will become a discipline field that examines social matters". This situation has been defined as "Sociologic Imperialism" by a researcher. When 
mentioning improving society it must not depart from its own aims. Of course it is the art educators that will balance between. It must not be forgotten that "Being as human in the world means, at least going after the BEAUTY" says Avsar Timucin. We must never forget that we are all look for the beauty whole our life.

All of the responsibility is shared by; artists, art and visual culture educators and us as researchers;

- Change and transformation must be directed in order to improve society,

- To possess enriched points of view in cultural concept,

- To research infinite opportunities aimed at individual creativity and to discuss this on a artistic based development ground.

- Try to find solutions to strengthen the bond between university, school and the art world,

- Ant the most important of all is that we must share our experiences on route. With this point of view and in the framework of approached we must be able to look ahead with more hope..

\section{References}

Atabek, E. (2003) Modern Dünyada değer kayması ve gençlik, Alkım Yayınevi, İstanbul

Berger, M., (1998) The crisis of criticism ,Ed.: Maurice Berger, The New Press New York.

Mc Fee, J. (1872) Society, Art and education: Concept in art and education, Ed:George Pappas

Ergun,D.,(1991) Türk bireyi kuramına giriş; Türk kültürünün olanakları, Gerçek Yayınevi.

Learmans,R.,(2002) Culture renewed -or how to understand current pluralism, A Must -a Muse Conference Culturnet werk-Netherland-Utrecht

Lash, S-Urry, J. (1994) Economics of sign and space. In Paul Duncum Visual Culture:

Developments, Definitions, and Directions for Art Education, Studies in Art Education 42(2), 101-111. 
Anadolu Journal of Educational Sciences International, Art Education Special Issue, November 2015

Uygur, N.,(2003) Kültür kuramı, YKY İstanbul. 